\title{
Faktor-faktor Yang Mempengaruhi Pendapatan Anggota Kelompok Tani Padi Sawah (Oriza sativa, L) di WKPP Kecamatan Peureulak Barat Kabupaten Aceh Timur
}

\author{
Muslimah $^{1} /$ Siti Muliana ${ }^{2}$ \\ ${ }^{1}$ Dosen Prodi Agribisnis Fakultas Pertanian \\ ${ }^{2}$ Alumni Prodi Agribisnis Fakultas Pertanian \\ UNIVERSITAS SAMUDRA
}

\section{RINGKASAN}

Faktor-faktor Yang Mempengaruhi Pendapatan Anggota Kelompok Tani Padi Sawah (Oriza sativa, L) di WKPP Kecamatan Peureulak Barat Kabupaten Aceh Timur. Tujuan Penelitian adalah mengetahui pengaruh penyuluhan, pencurahan tenaga kerja dan pendidikan terhadap pendapatan anggota kelompok tani padi sawah (Oryza sativa, L) di WKPP Kecamatan Peureulak Barat Kabupaten Aceh Timur.

Penelitian ini dilakukan dengan menggunakan metode survey. Lokasi penelitian di Kecamatan Peureulak Barat Kabupaten Aceh Timur dengan pertimbangan bahwa kecamatan tersebut terdapat kelompok tani yang melakukan kegiatan usahatani padi sawah. Penentuan desa sampel dilakukan dengan menggunakan metode Purposive Sampling. Populasi dalam penelitian ini adalah 38 orang. Rata-rata umur responden di daerah penelitian adalah 34 tahun, pengalaman dalam berusahatani padi sawah adalah 5,75 tahun, pendidikan 10,88 tahun, jumlah tanggungan keluarga 4 orang dan luas garapan sebesar 1,58 hektar.

Penggunaan tenaga kerja per usahatani adalah 14,29 HKP dan 57,15 HKP per hektar, total biaya per usahatani adalah sebesar Rp. 3.159.348,79, dan per hektar sebesar Rp. 12.637.395,15, produksi $2.759,87 \mathrm{~kg}$ per usahatani dan 11.039,47 kg per hektar, nilai produksi Rp.12.419.407,89 per usahatani dan Rp. 49.677.631,58 per hektar, pendapatan Rp. 9.260.059,11 per usahatani dan Rp. 37.040.236,43 per hektar.

Hasil analisis diperoleh persamaan regresi linier berganda sebagai berikut: $Y=22.693 .621,12$ $-1.386,80 X_{1}+52.916,96 X_{2}+29.836,36 X_{3}$. Hasil perhitungan diperoleh $R^{2}=0,93$ atau $93,00 \%$, Ini berarti faktor penyuluhan, pencurahan tenaga kerja dan pendidikan mempengaruhi tingkat pendapatan anggota kelompok tani padi sawah di WKPP kecamatan Peureulak Barat Kabupaten Aceh Timur sedangkan 7,00\% dipengaruhi oleh faktor yang tidak diteliti dalam penelitian ini.

Hasil penelitian secara serempak diperoleh penyuluhan, pencurahan tenaga kerja dan pendidikan mempengaruhi tingkat pendapatan anggota kelompok tani, sedangkan pengujian signifikan secara parsial dilakukan dengan uji $t$, dimana hasil dari pengujian pada parameter $\mathrm{X}_{1}, \mathrm{X}_{2}$, dan $X_{3}$ diperoleh faktor penyuluhan berpengaruh negatif, sedangkan faktor pendidikan dan pencurahan tenaga kerja berpengaruh sangat nyata terhadap peningkatan pendapatan petani padi sawah di WKPP kecamatan Peureulak Barat Kabupaten Aceh Timur Kata Kunci: Kelompok Tani, Pendapatan, Padi, Penyuluhan, Tenaga Kerja, Pendidikan

\section{PENDAHULUAN Latar Belakang}

Sektor pertanian masih memegang peranan penting dalam pembangunan ekonomi nasional. Karena Indonesia tergolong kedalam negara sedang berkembang dan pertanian memberikan kontribusi yang besar bagi pembangunan ekonomi Indonesia. Hal ini sesuai dengan yang dikemukakan oleh Widodo (2008: 1) yaitu "pertanian dapat memberikan kontribusi yang besar bagi pembangunan ekonomi yaitu sebagai kontribusi produksi, kontribusi pasar, kontribusi faktor produksi dan kontribusi devisa". Besarnya kontribusi yang disumbang dari sektor pertanian begitu saja dari perekonomian nasional, tapi justru sebaliknya sektor pertanian akan diberikan perhatian yang besar oleh pemerintah dengan menerapkan berbagai kebijakan, baik kebijakan dibidang produksi, pemasaran, begitu juga dengan bidang-bidang lainnya. 
Sebagaimana diketahui bahwa Kabupaten Aceh Timur yang dikenal sebagai daerah yang memiliki potensi sumberdaya alam yang sangat besar, memang hal itu tidak bisa dibantah, karena ini sangat didukung fakta dan kenyataan bahwa daerah ini merupakan bumi yang menyimpan potensi pertanian dan perkebunan. Potensi alam yang dimiliki Kabupaten Aceh Timur dimaksud meliputi sektor perkebunan, pertanian, perikanan, peternakan, kehutanan. Potensi perkebunan dan pertanian merupakan salah satunya terlihat seperti di Kecamatan Peureulak Barat. Beberapa Kecamatan yang ada di Aceh Timur tersebut pada saat ini telah menjadikan sektor pertanian jenis padi sawah menjadi potensi andalan yang telah banyak merubah taraf hidup warga ke arah yang semakin membaik.

Adapun luas lahan, produksi dan produktivitas padi sawah per Desa di Kecamatan Peureulak Barat dapat dilihat pada Tabel I-2 berikut:

Tabel I-2 Luas Lahan, Produksi Dan Produktivitas Padi Sawah Per Desa Di Kecamatan Peureulak Barat

\begin{tabular}{|l|l|l|l|l|}
\hline No & Nama Kampung & $\begin{array}{l}\text { Luas Lahan } \\
\text { ( Ha })\end{array}$ & $\begin{array}{l}\text { Produksi } \\
\text { ( Ton ) }\end{array}$ & $\begin{array}{l}\text { Produktivitas } \\
\text { ( Ton/ Ha ) }\end{array}$ \\
\hline 1 & Tempeun & 10,00 & 10,00 & 8,00 \\
2 & Kebon Tempeun & 10,00 & 40,00 & 4,00 \\
3 & Paya Biek & 4,00 & 28,00 & 7,00 \\
4 & Kabu & 5,00 & 25,00 & 5,00 \\
5 & Paya Sengat & 4,00 & 20,00 & 5,00 \\
6 & Mon Gedong & 4,00 & 20,00 & 5,00 \\
7 & Paya Gajah & 2,00 & 10,00 & 5,00 \\
8 & Beusa Baroh & 5,00 & 26,00 & 5,20 \\
9 & Alue Bu Tuha & 4,00 & 20,00 & 5,00 \\
10 & Alue Bu Tunong & 5,00 & 27,00 & 5,40 \\
11 & Beusa Seuberang & 8,00 & 8,00 & 7,00 \\
12 & Alue Bu Jalan & 6,00 & 28,00 & 4,67 \\
13 & Alue Bu Jalan Baroh & 8,00 & 35,00 & 4,37 \\
14 & Tanjung Tualang & 7,00 & 30,00 & 4,28 \\
15 & Beringin & 7,00 & 30,00 & 4,20 \\
\hline Jumlah & 89,00 & 357,00 & 79,12 \\
\hline
\end{tabular}

Sumber: Peureulak Barat dalam Angka, 2015

Berdasarkan Tabel I-2 dapat dilihat bahwa luas lahan yang tersedia untuk padi sawah per desa di Kecamatan Peureulak Barat adalah seluas $89,00 \mathrm{Ha}$ dengan produksi 357,00 Ton dan produktivitas sebanyak 79,12 Ton/Ha.

Penyuluhan pertanian diakui telah banyak memberikan sumbangan pada keberhasilan pembangunan pertanian di Indonesia. Penyuluh telah berhasil menyampaikan berbagai inovasi pertanian kepada petani dengan segala metodenya dengan ini maka para petani dapat meningkatkan pengetahuan dan keterampilannya serta dapat mengubah sikap petani menjadi mau dan mampu menerapkan inovasi baru, sehingga tujuan dari penyuluhan pertanian dapat tercapai, sebagaimana kutipan berikut:
Tujuan penyuluhan pertanian adalah untuk membantu para petani dan keluarganya dalam mencapai tingkat usahatani yang lebih efisien dan lebih produktif, untuk meningkatkan taraf kehidupan keluarga dan masyarakat yang lebih memuaskan melalui kegiatan-kegiatan terencana untuk mengembangkan pengertian, kemampuan dan kecakapan mereka sendiri sehingga memahami kemajuan ekonomi (Suhardiyono, 1990: 6).

Berdasarkan pernyataan di atas, tujuan penyuluhan pertanian untuk membantu keluarga petani dalam hal memecahkan berbagai masalah dalam usahataninya. Akan tetapi, dengan pengetahuan dan wawasan yang memadai hanya dapat digunakan untuk memecahkan 
sebagian dari masalah yang dihadapi petani. Oleh karena itu, sebagian petani tidak mau berpartisipasi dalam kegiatan penyuluhan pertanian dan bahkan petani tersebut tidak percaya dengan program yang diadakan oleh penyuluh pertanian. Namun penyuluh pertanian tetap berusaha membantu petani dalam mengatasi masalah yang dihadapi petani.

Tenaga penyuluhan pertanian diharapkan kedepan tidak lagi cukup hanya menguasai teknis budidaya pertanian saja, namun harus menguasai aspek pemasaran, permodalan, efesiensi ekonomi, dan analisis pendapatan petani, atau lebih lagi harus mampu menjadi konsultan dan pendamping petani dalam bisnis pertanian.

Penyuluh memiliki beberapa tugas pokok yang harus dilaksanakan dalam melaksanakan kegiatan penyuluhan pertanian. Tugas pokok tersebut dilaksanakan agar para petani mampu menerapkan teknologi baru, sehingga mampu berusaha tani dengan lebih baik, lebih menguntungkan dan dapat membentuk masyarakat tani yang lebih hidup sejahtera. (Suhardiyono. 1990: 26)

Rendahnya mutu sumberdaya manusia termasuk di sektor pertanian khususnya petani juga sebagian besar petugas/aparat teknis/penyuluhan pertanian. Sumberdaya manusia petani/pelaku agribisnis juga aparat penyuluh pertanian merupakan dua pilar pokok dalam pembangunan pertanian terutama pengembangan sistem dan usaha agribisnis. Sumberdaya manusia yang berkualitas merupakan prasyarat mutlak keberhasilan pembangunan pertanian dalam Kecamatan Peureulak Barat yang penduduk umumnya berusahatani padi sawah.

Dukungan sumberdaya manusia yang berkualitas melalui program penyuluhan pertanian dengan pendekatan kelompok yang dapat mendukung sistem agribisnis berbasis pertanian (tanaman pangan, hortikultura, peternakan dan perkebunan). Sehubungan dengan itu perlu dilakukan pembinaan dalam rangka penumbuhan dan pengembangan kelompok tani menjadi kelompok yang kuat dan mandiri untuk meningkatkan pendapatan petani dan kesejahteraan keluarganya.
Sasaran pencapaian program peningkatan kesejahteraan petani adalah memberantas kemiskinan di pedesaan, misalnya petani padi sawah yang terus menerus perlu mendapatkan perhatian pemerintah dalam berbagai kebijakan pembangunan sub sektor.

Untuk memudahkan pelaksanaan kegiatan penyuluhan dalam sektor pertanian, maka wilayah kerja penyuluh pertanian di bagi dalam wilayah kerja penyuluhan yang lebih kecil. Sebagai unit terkecil pembagian wilayah kerja adalah Wilayah Kerja Penyuluhan Pertanian yang disingkat dengan WKPP. Setiap WKPP dapat mewakili satu desa atau lebih. Seorang Penyuluh Pertanian Lapangan (PPL) bertanggung jawab terhadap pelaksanaan kegiatan penyuluhan bagi wilayah kelompok tani.

Pendapatan kelompok tani padi sawah di WKPP Kecamatan Peureulak Barat salah satunya dipengaruhi oleh penyuluhan yang di dapat oleh petani. Tingkat penyuluhan tentunya menjadikan pendidikan in formal untuk meningkatkan pengetahuan bagi petani sehingga dengan sendirinya pendapatan petani meningkat. Hal lain juga dipengaruhi oleh tingkat pencurahan tenaga kerja.

Berdasarkan kutipan di atas dapat diketahui bahwa tujuan dari pembangunan subsektor tanaman pangan dan hortikultura adalah dalam hal peningkatan produksi dan untuk meningkatkan kesejahteraan petani yang dicapai melalui peningkatan pendapatan, produksi dan produktivitas dalam berusahatani padi sawah.

\section{Identifikasi Masalah}

Apakah penyuluhan, pencurahan tenaga kerja dan pendidikan berpengaruh terhadap pendapatan anggota kelompok tani padi sawah (Oryza sativa L) di WKPP Kecamatan Peureulak Barat Kabupaten Aceh Timur?

\section{Tujuan Penelitian}

Untuk mengetahui pengaruh penyuluhan, pencurahan tenaga kerja dan pendidikan terhadap pendapatan anggota kelompok tani padi sawah (Oryza sativa L) di 
WKPP Kecamatan Peureulak Barat Kabupaten Aceh Timur.

\section{Hipotesis}

Penyuluhan, pencurahan tenaga kerja dan pendidikan berpengaruh terhadap pendapatan anggota kelompok tani padi sawah (Oryza Sativa, L) di WKPP Kecamatan Peureulak Barat Kabupaten Aceh Timur.

\section{METODOLOGI PENELITIAN}

\section{Lokasi, Objek, Ruang Lingkup dan Waktu penelitian}

Metode penelitian yang digunakan dalam penelitian ini adalah metode survey. Menurut Nazir, Moh (2005: 550), "Metode survey adalah penyelidikan untuk memperoleh fakta dari gejala-gejala dan mencari keterangan-keterangan secara faktual, baik tentang institusi sosial, ekonomi ataupun politik dari suatu kelompok atau suatu daerah". Lokasi penelitian yaitu Kecamatan Peureulak Barat Kabupaten Aceh Timur, dengan pertimbangan Kecamatan tersebut terdapat kelompok petani yang melakukan kegiatan usahatani padi sawah.

Objek dalam penelitian ini hanya dibatasi pada anggota kelompok tani WKPP Kecamatan Peureulak Barat yang mengusahakan tanaman padi sawah. Ruang lingkup penelitian ini meliputi pengaruh penyuluhan, pencurahan tenaga kerja dan pendidikan terhadap pendapatan anggota kelompok tani padi sawah di WKPP Kecamatan Peureulak Barat Kabupaten Aceh Timur. Waktu penelitian dilaksanakan pada bulan April sampai dengan bulan Agustus
2015 di Kecamatan Peureulak Barat Kabupaten Aceh Timur.

Teknik Penentuan Sampel dan Pengumpulan Data

Kecamatan Peureulak Barat Kabupaten Aceh Timur terdiri dari 7 Wilayah Kerja Penyuluh Pertanian (WKPP) yang di wakili oleh 15 desa. Dari 7 wilayah diambil 4 wilayah Purposive Sampling. Sugiyono (2008: 11) mengemukakan Purposive Sampling adalah sampling yang dilakukan dengan pertimbangan tertentu. Penelitian ini dengan pertimbangan bahwa wilayah tersebut merupakan wilayah yang memiliki penanaman padi sawah di WKPP Kecamatan Peureulak Barat Kabupaten Aceh Timur. Adapun wilayah tersebut yaitu WKPP I desa Beusa Seberang, WKPP II desa Tanjung Tualang dan Beringin, WKPP III desa Paya Gajah dan Beusa Baroh serta WKPP IV desa Aluebu Jalan dan Aluebu Jalan Baro.

Pengambilan petani sampel dilakukan dengan menggunakan metode Simple Random Sampling (Sampel Acak sederhana). Nazir (2005: 5) menyatakan bahwa Simple Random Sampling adalah pengambilan sampel dari populasi dimana tiap unit populasi mempunyai peluang yang sama untuk dipilih. Besarnya sampel yang diambil adalah $10 \%$ dari jumlah petani padi sawah.

Wirartha (2006: 238) mengemukakan dalam sampel random sederhana, anggota populasi tidak di pilah-pilah atau distrata terlebih dahulu. Semua anggota populasi langsung di pilih secara random (acak). Penelitian langsung merandom atau mengacak untuk mendapatkan ukuran sampel yang diinginkan. Adapun jumlah sampel dapat dilihat pada Tabel II-1 sebagai berikut:

Tabel II-1 Jumlah Populasi Petani Sampel di Daerah Penelitian Tahun 2014

\begin{tabular}{|l|l|l|ll|}
\hline No. & WKPP Sampel & $\begin{array}{l}\text { Jumlah Populasi } \\
\text { (Orang) }\end{array}$ & $\begin{array}{l}\text { Jumlah Sampel } \\
\text { (Orang) }\end{array}$ & \\
\hline 1 & WKPP I & 100 & 10 & \\
2 & WKPP II & 100 & 10 & \\
3 & WKPP III & 100 & 10 & \\
4 & WKPP IV & 80 & 8 & \\
\hline
\end{tabular}

Sumber: Data primer, 2015 (diolah) 
Dari Tabel II-1 dapat dilihat bahwa jumlah sampel seluruhnya yaitu sebanyak 38 orang yang terdiri dari WKPP I, WKPP II dan WKPP III sebanyak 10 orang, sedangkan WKPP IV 8 orang.

Data yang di kumpulkan dalam penelitian ini meliputi data primer dan data sekunder. Data primer dalam penelitian ini diperoleh dengan cara observasi, wawancara dan kuisioner (daftar pertanyaan). Data sekunder diperoleh dari instansi Pemerintah Kabupaten, Kecamatan, Desa maupun Perpustakaan untuk mendapatkan literatur sesuai dengan penelitian ini.

\section{Konsep Operasional Variabel}

1. Pendapatan $(\mathrm{Y})$ dalam penelitian ini adalah jumlah uang yang diterima petani dari aktivitasnya yang dihitung dengan satuan Rupiah

2. Penyuluhan dalam penelitian ini adalah proses pembelajaran bagi petani dalam usaha memberdayakan kelompok tani yang dinyatakan dalam skor dengan menggunakan skala likert yaitu "untuk mengukur sikap, pendapat dan persepsi seseorang atau sekelompok orang tentang fenomena sosial" (Sugiyono, 2008: 133)

Dengan kriteria pengukuran adalah sebagai berikut:

1) Sangat Setuju (SS) diberi skor 5

2) Setuju (ST) diberi skor 4

3) Ragu-Ragu (RG) diberi skor 3

4) Kurang Setuju (KS) diberi skor 2

5) Tidak Setuju (TS) diberi skor 1

3. Penggunaan tenaga kerja yaitu besarnya pencurahan tenaga kerja yang digunakan untuk usaha tani padi sawah per musim tanam berdasarkan luas areal yang diusahakan yang terdiri dari: tenaga kerja pria (HKP), wanita (HKW) dan anak-anak (HKA). Baik yang berasal dari dalam keluarga maupun luar keluarga. Untuk keseragaman tenaga kerja tersebut dikonversikan kedalam tenaga kerja pria (HKP) dengan rumus perhitungannya, menurut Collier, WL and Sajagjo dalam Mubyarto dan Suratno (1999: 210) adalah sebagai berikut:

$\mathrm{L}=\frac{t \times h \times j}{w} \times H K P$

Dimana:

$\mathrm{L} \quad=$ Indeks Tenaga Kerja (HKP)

$T=$ Jumlah tenaga Kerja

(Orang)

$\mathrm{H}$ = Jumlah Hari Kerja (Hari)

$\mathrm{j}=$ Jumlah Jam Kerja (Jam)

$\mathrm{w}$ = Rata-rata Jam Kerja per hari per orang (Jam)

4. Pendidikan dalam penelitian ini adalah lamanya pembelajaran formal yang di tempuh petani dengan satuan Tahun.

5. Pengalaman dalam penelitian ini adalah lamanya petani tersebut bekerja pada usaha tani padi sawah dengan satuan Tahun.

\section{Metode Analisis dan Pengujian Hipotesis}

Model yang digunakan untuk pengujian hipotesis dalam penelitian ini adalah analisis pendapatan dengan menggunakan regresi linier berganda. Analisis ini digunakan untuk mengetahui arah hubungan antara variabel bebas dengan variabel terikat. Hubungan tersebut bisa positif atau negatif dan untuk memprediksi nilai dari variabel terikat tersebut yaitu apabila nilai variabel bebas mengalami kenaikan atau penurunan. Variabel penelitian ini terdiri dari tiga variabel bebas dan satu variabel terikat yang persamaannya dapat ditulis sebagai berikut:

$\mathrm{Y}=\mathrm{a}_{0}+\mathrm{a}_{1} \mathrm{X}_{1}+\mathrm{a}_{2} \mathrm{X}_{2}+\mathrm{a}_{3} \mathrm{X}_{3}+\mathrm{e}$......... (Sudjana, 2005: 347)

Dimana:

$\mathrm{Y}=$ Pendapatan

$\mathrm{a}_{0} \quad=$ Intercept

$\mathrm{X}_{1} \quad=$ Penyuluhan (Skor)

$X_{2}=$ Pencurahan tenaga kerja (HKP)

$\mathrm{X}_{3} \quad=$ Pendidikan (Tahun)

Dalam analisis regresi berganda ada tiga jenis kriteria ketepatan, yaitu: 
1. Uji koefisien Determinan

Koefisien determinan $\left(R^{2}\right)$ bertujuan untuk mengetahui seberapa besar kemampuan variabel independen menjelaskan variabel dependen. Besarnya R Square berkisar antara 0-1. Semakin mendekati nol berarti model tidak baik atau variasi model dalam menjelaskan amat terbatas, sebaliknya semakin mendekati satu model semakin baik (Sudjana, 2005: 369). Dengan rumus sebagai berikut:

$\mathrm{R}^{2}=\frac{J K_{(r e g)}}{\sum Y_{i}^{2}}$ (Sudjana, 2005: 368)

2. Uji secara serempak (Uji F)

Uji secara serempak bertujuan untuk mengetahui pengaruh bersama-sama variabel independen terhadap variabel dependen, dengan rumus sebagai berikut:

$$
F_{\text {cari }}=\frac{J K_{\text {reg } / k}}{J K_{r e s} /(n-k-1)}
$$

...(Sudjana, $2005:$ 355)

Dimana: $\quad R^{2}=$ Koefisien determinasi

$\mathrm{N}=$ Jumlah Sampel

$\mathrm{K}=$ Parameter banyaknya

variabel bebas
Dengan kriteria pengambilan keputusan:

$\mathrm{H}_{\mathrm{o}}$ diterima jika $\mathrm{F}_{\text {hitung }}<\mathrm{F}$ tabel pada $\alpha=5 \%$

$\mathrm{H}_{\mathrm{a}}$ diterima jika $\mathrm{F}_{\text {hitung }}>\mathrm{F}_{\text {tabel }}$ pada $\alpha=5 \%$

3. Uji secara Parsial (Uji t)

Uji secara parsial (uji t) bertujuan untuk mengetahi besarnya pengaruh masingmasing variabel independen secara individual (parsial) terhadap variabel dependen, dengan rumus sebagai berikut:

$t_{\text {cari }}=\frac{a_{1}}{s_{a 1}} \ldots \ldots . . . .$. (Sudjana, 2005: 388)

Keterangan: $\mathrm{t}=\mathrm{uji}$ secara terpisah (parsial)

$\mathrm{a}_{1}=$ koefisien regresi yang

dicari

$$
\mathrm{S}_{\mathrm{a} 1}=\text { Standar error dari }
$$

koefisien

Dengan kriteria pengambilan keputusan:

$\mathrm{H}_{\mathrm{o}}$ diterima jika $\mathrm{t}_{\text {hitung }}<\mathrm{t}$ tabel pada $\alpha=5 \%$

$\mathrm{H}_{\mathrm{a}}$ diterima jika $\mathrm{t}_{\text {hitung }}>\mathrm{t}_{\text {tabel }}$ pada $\alpha=5 \%$

\section{HASIL PENELITIAN}

Karakteristik Responden

Untuk lebih jelasnya mengenai karakteristik responden di kecamatan Peureulak Barat dapat dilihat pada tabel V-1 berikut ini:

Tabel V-1. Karakteristik Responden di Kecamatan Peureulak Barat Kabupaten Aceh Timur

\begin{tabular}{|l|l|l|l|l|l|}
\hline No & $\begin{array}{l}\text { Desa } \\
\text { Sampel }\end{array}$ & $\begin{array}{l}\text { Umur } \\
\text { (Tahun) }\end{array}$ & $\begin{array}{l}\text { Pendidikan } \\
\text { (Tahun) }\end{array}$ & $\begin{array}{l}\text { Tanggungan } \\
\text { (Orang) }\end{array}$ & $\begin{array}{l}\text { Pengalaman } \\
\text { (Tahun) }\end{array}$ \\
\hline 1. & Paya Biek & 39,67 & 10,50 & 4,00 & 7,17 \\
2. & Paya Gajah & 39,78 & 10,00 & 3,00 & 10,44 \\
3. & Alue Bue Jalan & 39,75 & 9,75 & 4,00 & 10,50 \\
4. & Aluebu Jalan Baroh & 40,13 & 10,13 & 2,00 & 8,00 \\
5. & Tanjong Tualang & 39,40 & 9,00 & 3,00 & 11,20 \\
\hline \multicolumn{2}{|l|}{ Rata-rata } & 39,78 & 9,94 & 3,00 & 9,34 \\
\hline
\end{tabular}

Sumber: Data primer diolah

Dari tabel IV-1 dapat dilihat bahwa rata-rata umur responden di daerah penelitian adalah 39,78 tahun dengan tingkat pendidikan 10 tahun. Sedangkan pengalaman dalam bidang usahatani jagung rata-rata 9 tahun dengan jumlah tanggungan keluarga rata-rata 3,00 orang.

\section{Luas Lahan Garapan}

Untuk lebih jelasnya rata-rata luas lahan garapan usahatani jagung dari masingmasing desa sampel dapat dilihat pada tabel $\mathrm{V}-2$ berikut ini: 
Tabel V-2. Rata-rata Luas Lahan Garapan Usahatani Jagung di Kecamatan Kabupaten Aceh Timur, 2014

\begin{tabular}{|l|l|l|}
\hline No & Desa Sampel & Luas Lahan $(\mathrm{Ha})$ \\
\hline 1. & Paya Biek & 0,22 \\
2. & Paya Gajah & 0,24 \\
3. & Alue Bue Jalan & 0,23 \\
4. & Aluebu Jalan Baroh & 0,21 \\
5. & Tanjong Tualang & 0,23 \\
\hline Rata-rata & 0,22 \\
\hline
\end{tabular}

Sumber: Data primer diolah

Tabel V-2 di atas dapat dilihat bahwa rata-rata luas garapan usahatani jagung di daerah penelitian adalah sebesar 0,22 hektar.

Berdasarkan hasil penelitian dapat diketahui bahwa penggunaan biaya produksi usahatani jagung di kecamatan Peureulak Barat yaitu sebesar Rp. 148.161,46

\section{Biaya Produksi}

\section{Respon Petani}

Tabel V-4. Respon Petani Pada Usahatani Jagung di Kecamatan Peureulak Barat

\begin{tabular}{|l|l|l|l|l|l|l|}
\hline \multirow{2}{*}{ No. } & \multirow{2}{*}{ Uraian } & \multicolumn{2}{l|}{ Skor } & \\
\cline { 3 - 7 } 1 & & 5 & 4 & 3 & 2 & 1 \\
\cline { 2 - 7 } & $\begin{array}{l}\text { Tanaman jagung dengan curah hujan } \\
\text { ideal akan menghasilkan produksi } \\
\text { yang bagus }\end{array}$ & 22 & 4 & 4 & 1 & - \\
\hline 2 & $\begin{array}{l}\text { Usahatani jagung diperangaruhi oleh } \\
\text { tinggi dari tempat }\end{array}$ & 29 & - & - & - & - \\
\hline 3 & $\begin{array}{l}\text { Penanaman jagung dapat dilakukan } \\
\text { dua sampai tiga kali dalam setahun }\end{array}$ & 30 & 1 & 1 & - & - \\
\hline 4 & $\begin{array}{l}\text { Pengelolaan tanaman jagung dapat } \\
\text { dilakukan dengan beberapa cara } \\
\text { seperti penjarangan, penyulaman, } \\
\text { penyiangan dan pembubunan }\end{array}$ & 23 & 2 & - & 5 & 2 \\
\hline 5 & $\begin{array}{l}\text { Salah satu upaya untuk mendapatkan } \\
\text { hasil optimum adalah mengatur jarak } \\
\text { tanam. }\end{array}$ & 20 & 12 & - & - & - \\
\hline 6 & $\begin{array}{l}\text { untuk meningkatkan produksi jagung } \\
\text { maka petani melakukan pemupukan }\end{array}$ & 22 & 10 & - & - & - \\
\hline 7 & $\begin{array}{l}\text { Agar distribusi air lebih efektif ke } \\
\text { tanaman, petani umumnya membuat } \\
\text { saluran air di antara barisan tanaman }\end{array}$ & 26 & 6 & 1 & - & - \\
\hline 8 & $\begin{array}{l}\text { Petani melakukan pemeliharaan } \\
\text { dengan mengendalikan HPT, hal ini } \\
\text { karena gulma dapat menekan } \\
\text { pertumbuhan tanaman jagung } \\
\text { sehingga hasil jagung akan menurun }\end{array}$ & 25 & 7 & - & - & - \\
\hline 9 & $\begin{array}{l}\text { Petani melakukan panen jagung yang } \\
\text { merupakan tahap dari pasca panen }\end{array}$ & 32 & - & - & - & - \\
\hline
\end{tabular}

Lampiran: Data primer diolah 
Faktor Yang Mempengaruhi Pendapatan

Analisis faktor-faktor yang mempengaruhi pendapatan anggota kelompok tani jagung di WKPP kecamatan Peureulak Barat Kabupaten Aceh Timur dilakukan dengan menggunakan persamaan regresi linier berganda dengan 3 (tiga) variabel bebas yaitu penyuluhan, pencurahan tenaga kerja dan pendidikan. Sedangkan yang menjadi variabel terikat adalah pendapatan dari jagung. Hasil analisis diperoleh persamaan regresi linier berganda sebagai berikut:

$\mathrm{Y}=22.693 .621,12-1.386,80 \mathrm{X}_{1}+52.916,96 \mathrm{X}_{2}$ $+29.836,36 X_{3}$

Dari persamaan regresi dapat disimpulkan bahwa:

1. Jika pencurahan tenaga kerja dan pendidikan di anggap tetap, maka setiap penambahan penyuluhan 1 skor akan menurunkan pendapatan sebesar Rp. 1.386,80. Hal ini terjadi karena setiap penambahan program penyuluhan yang diterima petani maka akan mengurangi waktu petani didalam bersawah, karena waktu penyuluhan dilaksanakan pada pagi hari, dimana petani di daerah penelitian tidak bisa bersawah.

2. Jika penyuluhan dan pendidikan dianggap tetap maka setiap penambahan pencurahan tenaga kerja 1 HKP menyebabkan penambahan pendapatan sebesar Rp. 52.916,96. Hal ini terjadi karena semakin banyak tenaga kerja yang digunakan dalam usahatani jagung di daerah penelitian maka akan semakin cepat didalam pengelolaan usahatani sehingga akan mengurangi upah karena upah dihitung perhari kerja.

3. Jika penyuluhan dan pencurahan tenaga kerja dianggap tetap, maka setiap kenaikan tingkat pendidikan 1 tahun akan menyebabkan peningkatan pendapatan sebesar Rp. 29.836,36. Hal ini karena semakin tinggi pendidikan seorang petani maka akan semakin mudah dalam penyerapan teknologi.

Hasil perhitungan diperoleh $\mathrm{R}^{2}=0,93$ atau $93,00 \%$. Ini berarti faktor penyuluhan, pencurahan tenaga kerja dan pendidikan mempengaruhi tingkat pendapatan anggota kelompok tani jagung di WKPP kecamatan Peureulak Barat Kabupaten Aceh Timur sebesar $93,00 \%$ sedangkan 7,00\% dipengaruhi oleh faktor lain yang tidak diteliti dalam penelitian ini.

Untuk mengetahui besarnya pengaruh penyuluhan, pencurahan tenaga kerja dan pendidikan terhadap tingkat pendapatan anggota kelompok tani jagung di WKPP kecamatan Peureulak Barat Kabupaten Aceh Timur secara serempak di uji dengan menggunakan uji $\mathrm{F}$ dapat dilihat pada tabel berikut:

Tabel IV-7. Uji Secara Serempak (Uji F)

\begin{tabular}{|l|l|l|l|l|l|}
\hline \multirow{2}{*}{ Variabel } & \multirow{2}{*}{$\mathrm{F}_{\text {hitung }}$} & \multicolumn{2}{|l|}{$\mathrm{F}_{\text {tabel }}$} & \multicolumn{2}{l|}{ Kesimpulan } \\
\cline { 3 - 6 } & & $\alpha=0,05$ & $\alpha=0,01$ & $\alpha=0,05$ & $\alpha=0,01$ \\
\hline - Penyuluhan & & & & $F_{\text {hitung }}>$ & $\begin{array}{l}F_{\text {hitung }}> \\
F_{\text {Tabel }}\end{array}$ \\
\hline
\end{tabular}

Sumber: Data primer diolah

Berdasarkan tabel IV-7 hasil pengujian secara serempak (Uji F) diperoleh $F_{\text {hitung }}=141,57>$ $\mathrm{F}_{\text {Tabel }}=2,88$ pada tingkat kepercayaan $95 \%(\alpha$ $=0,05)$ dan $F_{\text {hitung }}=141,57>F_{\text {Tabel }}=4,42$ pada tingkat kepercayaan $99 \%(\alpha=0,01)$, sehingga dapat diambil kesimpulan bahwa secara serempak atau bersama-sama variabel penyuluhan, pencurahan tenaga kerja dan pendidikan berpengaruh terhadap tingkat pendapatan anggota kelompok tani jagung di
WKPP kecamatan Peureulak Barat Kabupaten Aceh Timur.

Besarnya pengaruh penyuluhan, pencurahan tenaga kerja dan pendidikan terhadap tingkat pendapatan anggota kelompok tani jagung di WKPP kecamatan Peureulak Barat Kabupaten Aceh Timur secara parsial di uji dengan menggunakan uji t dapat dilihat pada tabel berikut: 
Tabel IV-8. Uji Secara Parsial (Uji t)

\begin{tabular}{|c|c|c|c|c|c|}
\hline \multirow[b]{2}{*}{ Variabel } & \multirow[b]{2}{*}{$\mathrm{t}$ hitung } & \multicolumn{2}{|l|}{$\mathrm{t}_{\text {tabel }}$} & \multicolumn{2}{|l|}{ Kesimpulan } \\
\hline & & $\begin{array}{l}\alpha \\
0,05\end{array}=$ & $\begin{array}{ll}\alpha & = \\
0,01\end{array}$ & $\alpha=0,05$ & $\alpha=0,01$ \\
\hline - Penyuluhan & $-8.786,62$ & 1,697 & 2,457 & $\begin{array}{l}F_{\text {hitung }}> \\
\mathrm{F}_{\text {Tabel }}\end{array}$ & $\begin{array}{l}\text { F hitung > } \\
F_{\text {Tabel }}\end{array}$ \\
\hline - Pencurahan tenaga kerja & $341.452,96$ & 1,697 & 2,457 & $\begin{array}{l}F \text { hitung }> \\
F_{\text {Tabel }}\end{array}$ & $\begin{array}{l}F \text { hitung }> \\
F_{\text {Tabel }}\end{array}$ \\
\hline - Pendidikan & $410.019,06$ & 1,697 & 2,457 & $\begin{array}{l}F_{\text {hitung }}> \\
\mathrm{F}_{\text {Tabel }}\end{array}$ & $\begin{array}{l}\text { F hitung > } \\
F_{\text {Tabel }}\end{array}$ \\
\hline
\end{tabular}

Sumber: Data primer diolah

Berdasarkan Tabel IV-8 Hasil pengujian signifikan secara parsial dilakukan dengan uji $t$, dimana hasil dari pengujian pada parameter $\mathrm{X}_{1}, \mathrm{X}_{2}$ dan $\mathrm{X}_{3}$ diperoleh hasil sebagai berikut:

1. thitung untuk $t_{1}$ (penyuluhan) sebesar 8.786,62 dan $t_{\text {tabel }}$ sebesar 1,697 pada tingkat kepercayaan $95 \%$ dan 2,457 pada tingkat kepercayaan $99 \%$. Ini berarti secara parsial faktor penyuluhan berpengaruh sangat nyata terhadap tingkat pendapatan anggota kelompok tani jagung di WKPP kecamatan Peureulak Barat Kabupaten Aceh Timur.

2. $t_{\text {hitung }}$ untuk $t_{2}$ (pencurahan tenaga kerja) sebesar $341.452,96$ dan $t_{\text {tabel }}$ sebesar 1,697 pada tingkat kepercayaan 95\% dan 2,457 pada tingkat kepercayaan 99\%. Ini berarti secara parsial faktor pencurahan tenaga kerja berpengaruh sangat nyata terhadap tingkat pendapatan anggota kelompok tani jagung di WKPP kecamatan Peureulak Barat Kabupaten Aceh Timur.

3. $t_{\text {hitung }}$ untuk $t_{3}$ (pendidikan) sebesar 410.019,06 dan $t_{\text {tabel }}$ sebesar 1,697 pada tingkat kepercayaan $95 \%$ dan 2,457 pada tingkat kepercayaan $99 \%$. Ini berarti secara parsial faktor pendidikan berpengaruh sangat nyata terhadap tingkat pendapatan anggota kelompok tani jagung di WKPP kecamatan Peureulak Barat Kabupaten Aceh Timur.

\section{PENUTUP}

Kesimpulan

a. Rata-rata umur responden di daerah penelitian adalah 34 tahun, pengalaman dalam berusahatani padi sawah adalah 5,75 tahun, pendidikan 10,88 tahun, jumlah tanggungan keluarga 4 orang dan luas garapan sebesar 1,58 hektar.

b. Penggunaan tenaga kerja per usahatani adalah 14,29 HKP dan 57,15 HKP per hektar, total biaya per usahatani adalah sebesar Rp. 3.159.348,79, dan per hektar sebesar Rp. $12.637 .395,15$, produksi $2.759,87$ kg per usahatani dan $11.039,47 \mathrm{~kg}$ per hektar, nilai produksi Rp.12.419.407,89 per usahatani dan Rp. 49.677.631,58 per hektar, pendapatan Rp. 9.260.059,11 per usahatani dan Rp. 37.040.236,43 per hektar.

c. Hasil analisis diperoleh persamaan regresi linier berganda sebagai berikut:

$Y=22.693 .621,12-1.386,80 X_{1}+$ $52.916,96 X_{2}+29.836,36 X_{3}$

d. Hasil perhitungan diperoleh $\mathrm{R}^{2}=0,93$ atau 93,00\%, Ini berarti faktor penyuluhan, pencurahan tenaga kerja dan pendidikan mempengaruhi tingkat pendapatan anggota kelompok tani padi sawah di WKPP kecamatan Peureulak Barat Kabupaten Aceh Timur sedangkan $7,00 \%$ dipengaruhi oleh faktor yang tidak diteliti dalam penelitian ini.

e. Hasil penelitian secara serempak diperoleh penyuluhan, pencurahan 
tenaga kerja dan pendidikan mempengaruhi tingkat pendapatan anggota kelompok tani, sedangkan pengujian signifikan secara parsial dilakukan dengan uji $t$, dimana hasil dari pengujian pada parameter $\mathrm{X}_{1}, \mathrm{X}_{2}$, dan $X_{3}$ diperoleh faktor penyuluhan berpengaruh negatif, sedangkan faktor pendidikan dan pencurahan tenaga kerja berpengaruh sangat nyata terhadap peningkatan pendapatan petani padi sawah di WKPP kecamatan Peureulak Barat Kabupaten Aceh Timur

\section{Saran}

- Pemerintah perlu mendorong berkembangnya teknologi dan inovasi dalam bidang pertanian.

- Untuk mengendalikan stok pangan nasional perlu dibentuk suatu badan pengawasan pangan yang dapat mengawasi kondisi pangan. Dan dapat melakukan stabilisasi harga pangan nasional dan diharapkan supaya bisa membangun koordinasi yang baik dengan penyuluh pertanian.

- Para penyuluh pertanian hendaknya lebih meningkatkan lagi waktu yang diberikan kepada petani, hal ini supaya petani lebih memahami ilmu yang diberikan dan dapat diterapkannya dalam usahatani padi sawah. Dan diharapkan waktu penyuluhan diberikan pada sore hari, mengingat didaerah penelitian khususnya di kecamatan Peureulak Barat waktu pagi merupakan dimana petani sedang melakukan aktivitasnya seperti bersawah.

\section{DAFTAR PUSTAKA}

Anonymous. 2014. Surat Keputusan Menteri Pertanian No.273/Kpts.OT.210/1/ 1992
Anonymous. 2007. Surat Keputusan Menteri Pertanian No.273/Kpts/OT.160/4/2007

Daniel. 2002. Pengantar Ekonomi Pertanian, Bumi Aksara, Jakarta.

Liliweri, Alo. 1997. Komunikasi Antarpribadi. Bandung : Citra Aditya Bakti.

Mosher. 1997. Menggerakkan dan Membangun Pertanian. Yasa Guna. Jakarta

Mubyarto dan Suratno. 1999. Metodelogi Penelitian Ekonomi. Yayasan Agronomika. Yogyakarta

Muwardi. 1992. Pendapatan Usahatani. Sinar Harapan. Jakarta

Nazir, Moh. 2005. Metode Penelitian. Ghalia. Jakarta

Partadireja. 1997. Perhitungan Pendapatan Nasional. Rajawali Press. Jakarta

Purwanto. 2007. Penguatan Kelembagaan Kelompok Tani BPTP: Jawa Timur

Reksohadiprojo. 1982. Manajemen Strategi. Yogyakarta: BPFE

Samadi. 1997. Budidaya Padi Sawah. Kanisius. Yogyakarta

Syafruddin. 2003. Inovasi Pemasaran. Gramedia Pustaka Utama. Jakarta.

Soekartawi. 1998. Prinsip Dasar Manajemen Pemasaran Hasil Pertanian Teori dan Aplikasi. Rajawali Press. Jakarta.

Sugiyono. 2008. Metode Penelitian Kunatitatif Kualitatif. Alfabeta. Bandung

Suhardiyono. 1990. Petunjuk Bagi Penyuluh Pertanian. Erlangga. Jakarta

Sudjana. 2005. Teknik Analisa Regresi dan Korelasi. Tarsito. Bandung

Widodo, Sri. 2008. Campur Sari Agro Ekonomi. Libery. Yogyakarta

Wirartha, I Made. 2006. Metodologi Penelitian Sosial Ekonomi. Andi. Yogyakarta 